\section{Cooler Temperature During Germination Improves the Survival of Embryo Cultured Peach Seed}

\author{
Natalie Anderson ${ }^{1}$, David H. Byrne ${ }^{2}$, Jonathan Sinclair ${ }^{3}$, and \\ A. Millie Burrell ${ }^{3}$ \\ Department of Horticultural Sciences, Texas A\&MUniversity, College Station, \\ TX 77843-2133
}

Additional index words. Prunus persica, embryo rescue, nectarine

\begin{abstract}
Embryo culture techniques are employed to germinate seed of early ripening peach and nectarine [Prunus persica $($ L.) Batsch] cultivars. Generally, the embryos in these genotypes do not mature by the time the fruit matures, thus rendering normal stratification procedures ineffective. In 1998 and 1999, immature embryos from multiple peach genotypes were cultured in an embryo rescue medium (Woody Plant Medium, $3 \%$ sucrose, $0.065 \%$ agar) at $5{ }^{\circ} \mathrm{C}$ for 45 days in the dark. Embryos were then placed under lights at either a cool-temperature $\left(18{ }^{\circ} \mathrm{C}\right.$ in 1999 and $20^{\circ} \mathrm{C}$ in 1998) or a warm-temperature (30 ${ }^{\circ} \mathrm{C}$ in 1999 and $28{ }^{\circ} \mathrm{C}$ in 1998 ) treatment with a photoperiod of 12 hours for germination and initial growth. After 2-4 weeks, embryos were rated for germination, root number, and top growth. The embryos incubated at the cool-temperature regime not only had better germination, but also had a higher rate of greenhouse survival.
\end{abstract}

For many years, embryo culture has been used to rescue embryos that would not survive under normal germination conditions. Many advances have been made in the techniques and the media type used for embryo culture (Bridgen, 1994; Emershad and Ramming, 1994; Ramming 1990). Temperature has been reported to affect embryo enlargement of in ovule cultured peach [Prunus persica (L.) Batsch] embryos (Ramming, 1985), the frequency of rosetting of young peach seedlings (Byrne et al., 2000), and the growth of in vitro cultured peach rootstocks (Loreti et al., 1988). No reports were found on the response of embryo cultured peaches to temperature during germination after cold stratification. In fact, many articles do not indicate the temperature used during germination. In recent works, the temperatures indicated were $25^{\circ} \mathrm{C}$ (Rizzo et al., 1998) and $15.5^{\circ} \mathrm{C}(10 \mathrm{~d}) / 25^{\circ} \mathrm{C}$ (subsequent growth) (Emershad and Ramming, 1994).

\section{Materials and Methods}

In 1998 and 1999, immature embryos from multiple peach genotypes (Tables 1 and 2) were cultured in an embryo rescue medium \{Woody Plant Medium (WPM), 3\% sucrose, $0.065 \%$ agar $\}$ at $5{ }^{\circ} \mathrm{C}$ for $45 \mathrm{~d}$ in the dark (Rizzo et al., 1998). The cultured embryos (13 $\mathrm{mm}$ average length) were then placed under florescent lights at either a cool-temperature $\left(20^{\circ} \mathrm{C}\right.$ in 1998 or $18{ }^{\circ} \mathrm{C}$ in 1999$)$ or a warmtemperature $\left(28^{\circ} \mathrm{C}\right.$ in 1998 or $30^{\circ} \mathrm{C}$ in 1999) treatment with a photoperiod of $12 \mathrm{~h}$ for ger-

Received for publication 6 Feb. 2001. Accepted for publication 31 July 2001.

${ }^{1}$ Laboratory Technician.

${ }^{2}$ Professor.

${ }^{3}$ Graduate Student. mination and initial growth. After 2-4 weeks, embryos were evaluated for germination, root number, and in 1999 top growth. Root number was classified as: $1=$ less than 5 roots, $2=5$ 10 roots, $3=11-20$ roots, and $4=21$ or more roots. Top growth was rated as follows: $1=$ 21 or more roots. embryo cultured peach seed in 1999 . $^{2}$ are not significantly different at the 5\% level. dead embryo; $2=$ white/green embryo with no shoot formation; 3 = weak growth with shoot dieback; 4 = weak, unhealthy growth; and $5=$ healthy shoot formation. If embryos had a root number rating of 2-4 and a top rating from $3-$ 5 , they were removed from culture 2-4 weeks after placement under florescent lights, transplanted into $2.5^{\prime \prime} \times 1.5^{\prime \prime} \times 2.5^{\prime \prime}$-pots with Sunshine Mix \#4, and acclimated to greenhouse conditions. In 1999, survivability (percentage of live plants) was determined after 6-8 weeks of growth in the greenhouse.

\section{Results and Discussion}

In both years, germination and root growth were better or no different for individual genotypes and better on the average at the lower temperature as compared to the higher temperature (Tables 1 and 2). In 1999, this increased germination and root growth is reflected in the greater top growth and survival of embryos germinated at the lower temperature regime. Furthermore, observations showed that higher temperatures caused substantial shoot dieback to occur (Fig. 1).

Although there is a lack of information specifically published on stone fruits, evidence exists that cooler temperatures during germination are beneficial for woody ornamental species (Meyer, 1988). This suggests that the better germination may be correlated to the temperature experienced by the species during seed germination under natural conditions.

This simple procedure increased peach

Table 1. Effects of temperature during germination on the germination and root number of embryo cultured peach seed in $1998 .{ }^{2}$

\begin{tabular}{|c|c|c|c|c|c|}
\hline \multirow[b]{2}{*}{ Cultivar } & \multirow{2}{*}{$\begin{array}{c}\text { Total embryos } \\
\text { tested }\end{array}$} & \multicolumn{2}{|c|}{$\begin{array}{c}\text { Germination } \\
(\%)\end{array}$} & \multicolumn{2}{|c|}{$\begin{array}{c}\text { Root no. } \\
\text { rating }\end{array}$} \\
\hline & & $20^{\circ} \mathrm{C}$ & $28^{\circ} \mathrm{C}$ & $20^{\circ} \mathrm{C}$ & $28^{\circ} \mathrm{C}$ \\
\hline Spring Brite & 518 & $92 \mathrm{a}$ & $69 \mathrm{~b}$ & $3.2 \mathrm{a}$ & $2.4 \mathrm{~b}$ \\
\hline Richlady & 932 & $92 \mathrm{a}$ & $72 \mathrm{~b}$ & $3.0 \mathrm{a}$ & $2.0 \mathrm{~b}$ \\
\hline Diamond Ray & 155 & $97 \mathrm{a}$ & $70 \mathrm{~b}$ & $3.5 \mathrm{a}$ & $2.7 \mathrm{~b}$ \\
\hline Overall & 1605 & $93 \mathrm{a}$ & $71 \mathrm{~b}$ & $3.2 \mathrm{a}$ & $2.2 \mathrm{~b}$ \\
\hline
\end{tabular}

${ }^{2}$ Mean separation in rows by Duncan's multiple range test. Means within a row followed by the same letter are not significantly different at the $5 \%$ level.

${ }^{\mathrm{y}}$ Root number ratings: $1=$ less than 5 roots, $2=5-10$ roots, $3=11-20$ roots, and $4=$

Table 2. Effects of temperature during germination on the germination, root number and top growth of

\begin{tabular}{|c|c|c|c|c|c|c|c|c|c|}
\hline \multirow[b]{2}{*}{ Cultivar } & \multirow{2}{*}{$\begin{array}{c}\text { Total embryos } \\
\text { tested }\end{array}$} & \multicolumn{2}{|c|}{$\begin{array}{c}\text { Germination } \\
(\%)\end{array}$} & \multicolumn{2}{|c|}{$\begin{array}{c}\text { Root no. } \\
\text { rating }^{y}\end{array}$} & \multicolumn{2}{|c|}{$\begin{array}{c}\text { Top growth } \\
\text { rating }^{\mathrm{x}}\end{array}$} & \multicolumn{2}{|c|}{$\begin{array}{c}\text { Survival } \\
(\%)\end{array}$} \\
\hline & & $\overline{18{ }^{\circ} \mathrm{C}}$ & $30^{\circ} \mathrm{C}$ & $\overline{18^{\circ} \mathrm{C}}$ & $30^{\circ} \mathrm{C}$ & $\overline{18^{\circ} \mathrm{C}}$ & $30^{\circ} \mathrm{C}$ & $18^{\circ} \mathrm{C}$ & $30^{\circ} \mathrm{C}$ \\
\hline Sunmist & 187 & $66 \mathrm{a}$ & $76 \mathrm{a}$ & $2.2 \mathrm{a}$ & $2.1 \mathrm{a}$ & $4.7 \mathrm{a}$ & $4.5 \mathrm{a}$ & $62 a$ & $63 \mathrm{a}$ \\
\hline TX2293-1 & 138 & $77 \mathrm{a}$ & $51 \mathrm{~b}$ & $2.3 \mathrm{a}$ & $1.9 \mathrm{a}$ & $4.5 \mathrm{a}$ & $3.7 \mathrm{~b}$ & $75 \mathrm{a}$ & $46 \mathrm{~b}$ \\
\hline TX2293-2 & 279 & $67 \mathrm{a}$ & $54 \mathrm{a}$ & $2.4 \mathrm{a}$ & $2.2 \mathrm{a}$ & $4.4 \mathrm{a}$ & $3.9 \mathrm{~b}$ & $56 \mathrm{a}$ & $49 \mathrm{a}$ \\
\hline TX2293-3 & 169 & $94 \mathrm{a}$ & $91 \mathrm{a}$ & $2.7 \mathrm{a}$ & $2.5 \mathrm{a}$ & $4.9 \mathrm{a}$ & $4.8 \mathrm{a}$ & $81 \mathrm{a}$ & $94 \mathrm{a}$ \\
\hline TX3290-2 & 112 & $92 \mathrm{a}$ & $58 \mathrm{~b}$ & $2.7 \mathrm{a}$ & $2.3 \mathrm{a}$ & $4.7 \mathrm{a}$ & $4.1 \mathrm{~b}$ & $66 \mathrm{a}$ & $24 \mathrm{~b}$ \\
\hline & 148 & $68 \mathrm{a}$ & $17 \mathrm{~b}$ & $2.5 \mathrm{a}$ & $1.0 \mathrm{~b}$ & $4.6 \mathrm{a}$ & $3.2 \mathrm{~b}$ & $13 \mathrm{a}$ & $6 \mathrm{a}$ \\
\hline TX2A36 & 198 & $81 \mathrm{a}$ & $60 \mathrm{a}$ & $2.9 \mathrm{a}$ & $2.0 \mathrm{~b}$ & $4.7 \mathrm{a}$ & $4.0 \mathrm{~b}$ & $56 \mathrm{a}$ & $39 \mathrm{a}$ \\
\hline TX2B1 & 251 & $79 a$ & $74 \mathrm{~b}$ & $3.4 \mathrm{a}$ & $2.9 \mathrm{~b}$ & $4.8 \mathrm{a}$ & $4.3 \mathrm{~b}$ & $65 \mathrm{a}$ & $33 \mathrm{~b}$ \\
\hline TX2B3 & 93 & $56 \mathrm{a}$ & $54 \mathrm{a}$ & $2.1 \mathrm{a}$ & $1.8 \mathrm{a}$ & $4.3 \mathrm{a}$ & $4.1 \mathrm{a}$ & $37 \mathrm{a}$ & $48 \mathrm{a}$ \\
\hline TX2B6 & 199 & 89 a & $76 \mathrm{a}$ & $3.0 \mathrm{a}$ & $2.9 \mathrm{a}$ & $4.6 \mathrm{a}$ & $4.1 \mathrm{a}$ & $70 \mathrm{a}$ & $20 \mathrm{~b}$ \\
\hline TX2B7N & 100 & $74 \mathrm{a}$ & $47 \mathrm{~b}$ & $2.5 \mathrm{a}$ & $1.7 \mathrm{~b}$ & $4.8 \mathrm{a}$ & $3.9 \mathrm{~b}$ & $33 \mathrm{a}$ & $35 \mathrm{a}$ \\
\hline Overall & 1874 & $75 \mathrm{a}$ & $62 \mathrm{~b}$ & $2.6 \mathrm{a}$ & $2.2 \mathrm{~b}$ & $4.6 \mathrm{a}$ & $4.1 \mathrm{~b}$ & $58 \mathrm{a}$ & $42 \mathrm{~b}$ \\
\hline
\end{tabular}

${ }^{2}$ Mean separation in rows by Duncan's multiple range test. Means within a row followed by the same letter

${ }^{y}$ Root number ratings: $1=$ less than 5 roots, $2=5-10$ roots, $3=11-20$ roots, and $4=21$ or more roots.

${ }^{x}$ Top growth rated as follows: $1=$ dead embryo, 2 = white/green embryo with no shoot formation, $3=$ weak growth with top dieback, 4 = weak, unhealthy growth, $5=$ healthy shoot formation. 


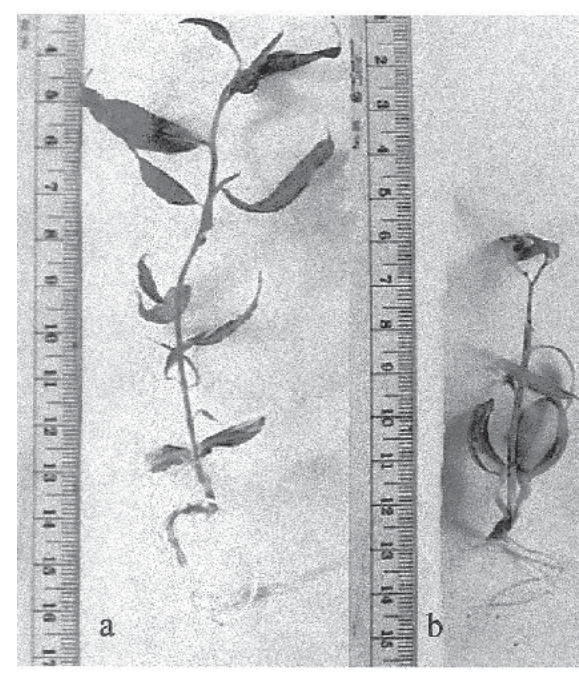

Fig. 1. 'Richlady' seedlings germinated at cool temperature (a) and warm temperature (b). embryo germination an average of $22 \%$ in 1998 and $13 \%$ in 1999 and increased survival in the greenhouse $16 \%$ in 1999. This is a large effect, which emphasizes the importance of controlling temperature when growing out embryo cultured peach embryos and other similar in vitro propagules.

\section{Literature Cited}

Bridgen, M.P. 1994. A review of plant embryo culture. HortScience 29:1243-1246.

Byrne, D.H., W. Sherman, and T. Bacon. 2000. Stone fruit genetic pool and its exploitation for growing under warm winter conditions, p. 157230. In: A. Erez (ed.). Temperate fruit crops in warm climates. Kluwer Academic Publishers.

Emershad, R. and D.W. Ramming. 1994. Effects of media on embryo enlargement, germination and plant development in early-ripening genotypes of Prunus grown in vitro. Plant Cell, Tissue and Organ Culture 37:55-59.

Loreti, F., S. Morini, and P.L. Pasqualetto. 1988 Effect of alternating temperature during proliferation and rooting stages of GF 655/2 and GF 677 shoots cultured in vitro. Acta Hort. 227:467469.

Meyer, Martin M. 1988. Rest and postdormancy of seeds of Contoneaster species. HortScience 23:1046-1047.

Ramming, D.W. 1985. In ovulo embryo culture of early maturing Prunus.HortScience 20:419420.

Ramming, D.W. 1990. The use of embryo culture in fruit breeding. HortScience 25:393-398.

Rizzo, M., K. Porter, D. Bassi, and D.H. Byrne. 1998. Growth of immature peach (Prunuspersica [L.] Batsch) embryos on different media. Acta Hort. 465:141-144. 